\title{
Resistance, Extinction, and Everything in Between - The Diverse Responses of Seaweeds to Marine Heatwaves
}

\author{
Sandra C. Straub ${ }^{1 *}$, Thomas Wernberg ${ }^{1,2}$, Mads S. Thomsen ${ }^{1,3}$, Pippa J. Moore ${ }^{4,5}$, \\ Michael T. Burrows ${ }^{6}$, Ben P. Harvey ${ }^{4,7}$ and Dan A. Smale ${ }^{1,8}$ \\ 1 UWA Oceans Institute and School of Biological Sciences, University of Western Australia, Crawley, WA, Australia, \\ ${ }^{2}$ Department of Science and Environment, Roskilde University, Roskilde, Denmark, ${ }^{3}$ Centre of Integrative Ecology, Marine \\ Ecology Research Group, School of Biological Sciences, University of Canterbury, Christchurch, New Zealand, ${ }^{4}$ Institute \\ of Biological, Environmental and Rural Sciences, Aberystwyth University, Aberystwyth, United Kingdom, ${ }^{5}$ Centre for Marine \\ Ecosystems Management, Edith Cowan University, Joondalup, WA, Australia, ${ }^{6}$ Scottish Association for Marine Science, \\ Scottish Marine Institute, Oban, United Kingdom, ${ }^{7}$ Shimoda Marine Research Center, University of Tsukuba, Shimoda \\ Japan, ${ }^{8}$ Marine Biological Association, The Laboratory, Citadel Hill, Plymouth, United Kingdom
}

Globally, anomalously warm temperature events have increased by 34\% in frequency and $17 \%$ in duration from 1925 to 2016 with potentially major impacts on coastal ecosystems. These "marine heatwaves" (MHWs) have been linked to changes in primary productivity, community composition and biogeography of seaweeds, which often control ecosystem function and services. Here we review the literature on seaweed responses to $\mathrm{MHWs}$, including 58 observations related to resistance, bleaching, changes in abundance, species invasions and local to regional extinctions. More records existed for canopy-forming kelps and bladed and filamentous turf-forming seaweeds than for canopy-forming fucoids, geniculate coralline turf and crustose coralline algae. Turf-forming seaweeds, especially invasive seaweeds, generally increased in abundance after a MHW, whereas native canopy-forming kelps and fucoids typically declined in abundance. We also found four examples of regional extinctions of kelp and fucoids following specific MHWs, events that likely have long term consequences for ecological structure and functioning. Although a relatively small number of studies have described impacts of MHWs on seaweed, the broad range of documented responses highlights the necessity of better baseline information regarding seaweed distributions and performance, and the need to study specific characteristics of MHWs that affect the vulnerability and resilience of seaweeds to these increasingly important climatic perturbations. A major challenge will be to disentangle impacts caused by the extreme temperature increases of MHWs itself from co-occurring potential stressors including altered current patterns, increasing herbivory, changes in water clarity and nutrient content, solar radiation and desiccation stress in the intertidal zone. With future increases anticipated in the intensity, duration and frequencies of MHWs, we expect to see more replacements of large long-lived habitat forming seaweeds with smaller ephemeral seaweeds, reducing the habitat structure and effective services seaweed-dominated reefs can provide.

Keywords: temperature extremes, temperature anomalies, climate variability, extreme climatic events, macroalgae, foundation species, habitat formers, range contraction 


\section{INTRODUCTION}

Anthropogenic stressors have resulted in widespread changes in coastal marine ecosystems (Perry et al., 2005; Sorte et al., 2010; Pecl et al., 2017), with increased temperature being one of the most pervasive environmental drivers of change (HoeghGuldberg and Bruno, 2010; Wernberg et al., 2011a; Smale et al., 2019). It is estimated that $>70 \%$ of the world's coastlines have experienced significant warming in the past four decades (Lima and Wethey, 2012), with predicted near-surface warming in the order of $2-7^{\circ} \mathrm{C}$ by the end of the century (Christensen et al., 2007; Lima and Wethey, 2012). As a consequence of continued ocean warming, $46 \%$ of the world's coastlines have experienced a significant decrease in the frequency of cold days, whereas $38 \%$ of coastlines have experienced an increased frequency of extremely hot days when sea surface temperature (SST) exceed the 95th percentile of standardized anomalies of the raw SST between 1982-2010 (Lima and Wethey, 2012). Recently, Hobday et al. (2016) proposed a framework for describing anomalously warm water events as "marine heatwaves" (MHWs), which included a quantitative definition of periods when SSTs exceed the 90th percentile of the climatological mean for at least five consecutive days. Using this approach, Oliver et al. (2018) empirically showed that MHWs have increased in both frequency and duration since the early 20th century, by 34 and $17 \%$, respectively. The underlying driver of this trend was primarily increased mean ocean temperature (Frölicher et al., 2018; Oliver et al., 2018, 2019), with projections of MHWs under a range of climate change scenarios showing they will likely increase in intensity, frequency and duration with ongoing climate change (Frölicher et al., 2018). Furthermore, MHWs are the direct result of local-scale processes (e.g., ocean heat advection, vertical mixing) which can be suppressed or enhanced by remote influences (e.g., climate modes such as ENSO) (Holbrook et al., 2018). Often, there are multiple drivers that significantly influence the occurrence of a $\mathrm{MHW}$, resulting in temperature extremes being generally accompanied by a multitude of altered environmental factors such as ocean currents, wave action, solar radiation and in the intertidal zone, desiccation stress. This co-occurrence of changes in many environmental conditions makes it difficult to disentangle the interactive effects of different factors during MHWs.

Some MHWs have had significant impacts on marine ecosystems, with substantial ecological and socio-economic consequences (Madin et al., 2012; Pecl et al., 2017; Frölicher and Laufkötter, 2018; Smale et al., 2019). Responses include coral bleaching (Couch et al., 2017; Hoegh-Guldberg and Poloczanska, 2017; Le Nohaïc et al., 2017), loss of kelp forest (Wernberg et al., 2016; Thomsen and South, 2019; Thomsen et al., 2019), increased surface layer stratification (Bond et al., 2015; Schaeffer and Roughan, 2017), mass mortalities of marine invertebrates (Garrabou et al., 2009; Oliver et al., 2017), rapid range shifts (Smale and Wernberg, 2013), restructuring of communities (Wernberg et al., 2013a; Bennett et al., 2015b), and fisheries closures (Caputi et al., 2016, 2019; Oliver et al., 2017). In contrast to the impacts of long-term gradual warming, MHWs can outpace adaptive capabilities and cause sudden and dramatic regime shifts that are more difficult to predict and manage (Scheffer and Carpenter, 2003; Andersen et al., 2009; Wernberg et al., 2016). Moreover, biological responses to MHWs can have devastating consequences for local economies, in particular affecting commercial fisheries, which rely on healthy ecosystem functioning for their productivity (Mills et al., 2013; Bennett et al., 2016; Caputi et al., 2016; Wernberg et al., 2019). Observations of these extreme events show that MHWs are key drivers of ecosystem-scale change, and demonstrate the drastic consequences MHWs can have on the structure and function of marine communities and ecosystems (Dayton and Tegner, 1983; Pearce and Feng, 2013; Wernberg et al., 2013a).

Seaweeds (marine macroalgae) are large, multicellular algae which often dominate shallow-water rocky ecosystems where they can form extensive marine forests (Wernberg and Filbee-Dexter, 2019). Seaweeds represent essential components of coastal habitats and underpin highly diverse ecosystems (Wernberg et al., 2013a; Bennett et al., 2016; Teagle et al., 2017). As important primary producers and habitat formers, seaweeds influence shallow-water communities on rocky reefs globally (Dayton, 1985; Tegner et al., 1997; Bertness et al., 1999; Wernberg et al., 2003; Buschbaum et al., 2006; Tuya and Thomsen, 2009; Egan et al., 2014). Kelp forests, extensive reef systems dominated by large laminarian and fucalean seaweeds (Steneck and Johnson, 2013; Wernberg and Filbee-Dexter, 2019; Wernberg et al., 2019), are especially important for local communities as they directly modify the environment surrounding them and influence adjacent habitats (Gaylord et al., 2007; Wernberg et al., 2018b). Most canopy-forming seaweed species are adapted to thrive in cool, clear, nutrient-rich waters, which makes them vulnerable to anthropogenic stressors influencing water clarity and to ocean warming in warmer parts of their distributions (Fernandez, 2011). Consequently, substantial changes in seaweed distribution and abundance have been observed in various ecoregions over the last five decades due to global change (Lima et al., 2007; Wernberg et al., 2011b; Krumhansl et al., 2016; Filbee-Dexter and Wernberg, 2018; Casado-Amezúa et al., 2019) as well as recent changes due to MHWs (Carballo et al., 2002; Vergés et al., 2014a; Mathiesen, 2016; Reed et al., 2016; Wernberg et al., 2016; Thomsen et al., 2019).

Ocean warming threatens seaweeds as the performance of populations and individuals are affected both directly and indirectly by warming. Warming can directly affect the physiology of seaweeds (Van den Hoek, 1982; Kordas et al., 2011; Tuya et al., 2012; Wernberg et al., 2013b) through sublethal stress leading to reduced performance and increased vulnerability to other stressors (Wernberg et al., 2010). Indirect effects include changes in species interactions, such as shifts in competitive hierarchies and over-consumption by rangeshifting herbivores (Haraguchi et al., 2009; Ling et al., 2009; Vergés et al., 2014a; Bennett et al., 2015b; Franco et al., 2015). Pervasive warming of long duration and magnitude, with potential interaction with additional stressors such as solar radiation, desiccation stress and eutrophication, can ultimately exceed a species' lethal thermal limits (Van den Hoek, 1982). Exceeding the sublethal thermal threshold of a species leads to failure to reproduce in marginal populations (causing population 
attrition), and can result in local to regional extinctions and ultimately range contractions (O'Brien and Scheibling, 2016; Wernberg and Straub, 2016; Wernberg et al., 2016; Smale et al., 2019).

Overall, increasing temperatures and MHWs directly and indirectly alter the distribution and abundance of seaweeds, their associated species and interactions between species with cascading effects on ecosystem functions and the provision of ecosystem services (Harley et al., 2012; Vergés et al., 2014a; Wernberg and Straub, 2016; FilbeeDexter and Wernberg, 2018; Thomsen and South, 2019). Given the expected increase in the frequency and duration of MHWs, it is crucial to understand MHW impacts on underlying biological mechanisms which lead to changes in the abundance, distribution and function of foundation species such as seaweeds (IPCC, 2007; Kirtman et al., 2013; Oliver et al., 2018). Recent MHWs have caused substantial ecological changes with economic consequences across marine systems globally (Frölicher and Laufkötter, 2018; Smale et al., 2019). However, little is known about how these extreme events have impacted seaweeds and comprehensive overviews are lacking (but see Smale et al., 2019). Here, we review documented impacts of MHWs on seaweeds, highlighting the diversity of observed responses.

\section{MATERIALS AND METHODS}

We conducted a literature search using the library search portal at the University of Western Australia, ResearchGate, Google Scholar and the reference lists of papers returned in the search. We included only MHWs observed in natural ecosystems, not experiments that aimed to mimic MHWs (e.g., Gouvea et al., 2017). Keywords used in the literature search included "marine heatwave*" "marine heat wave," "unusually warm," "abnormally warm," "abnormal temperature," "positive temperature event*", "extreme event*," "hot summer" in combination with "marine," "seaweed*" "macroalga*, "turf" and "crustose coralline alga*." The cut-off date for this general search was 15th of February 2019. News articles were only included where no peer-reviewed journal articles could be found.

The identified literature was screened using the MHW definition (Hobday et al., 2016) for occurrence of an unusual extreme temperature event. Due to the nature of MHWs, the extreme temperature anomalies which define these events (Hobday et al., 2016) co-occur with multiple alterations in the affected ecosystems such as current patterns, increased surface layer stratification, increased desiccation stress in the intertidal zone, altered wave activity and likelihood of strong storms. Contribution of these factors to observed impacts on organisms cannot be disentangled with certainty yet. Hence for the purpose of this paper, reported effects are discussed and categorized as MHW effects on the study organisms and ecosystems.

The observations of seaweed responses to MHW events identified through the literature search were assigned to five broad categories based on the severity of their biological response (Figure 1): responses were not observable or confined to negligible sublethal stress (group 1, resistance); visible signs of sublethal stress (group 2, physiological performance, e.g., tissue bleaching); altered ecological interactions (group 3, ecological performance, e.g., changes in reproduction or herbivory affecting competition and consumer pressure); altered abundance (group 4 , changes in abundance of native species or arrivals of invasive species), and; widespread seaweed mortality (group 5, range shifts and local to regional extinction).

The observed seaweed species were also categorized into functional groups based on their growth forms: crust (CCA: crustose coralline algae); turf-forming seaweeds (bladed, filamentous and GCA: geniculate coralline algae) and canopyforming seaweeds (kelp, fucoids). Information was combined to determine how many observations existed per broad response group for each functional group.

\section{RESULTS}

A total of 58 observations of seaweed responses to MHWs were identified, reported in 17 peer-reviewed papers and three additional news articles (Table 1), often with multiple observations per seaweed group. Resistance $(n=3)$ and extinctions $(n=4)$ were least frequently reported, and bleaching was observed in only one event for six turf-forming red seaweeds and one brown kelp $(n=7)$. The majority of records were changes in abundance; turf-forming seaweeds typically increased in abundance $(n=18)$ whereas large canopyformers declined in abundance ( $n=17$; Figure 2). Overall, 25 observations were found for canopy-forming seaweeds, 29 observations for turf-forming seaweeds and only four observations for CCA. However, there could be a bias in reported observations toward large, conspicuous canopy-formers, with better baseline data availability or because changes are easier to detect for larger species. Additionally, publication bias is likely against reporting resistance or negligent effects with increased likelihood of publication for studies that detect and report largescale changes.

\section{Physiological Performance}

Tissue bleaching is a good primary indicator of experienced sublethal stress (Hawkins and Hartnoll, 1985). Changes to seaweed condition was categorized as visible discoloration (whitening or turning greenish) of the blade tissue due to loss of surface integrity. This indicates loss or reduction in pigmentation, which in turn is associated with reduced photosynthetic performance (Marzinelli et al., 2015; Xiao et al., 2015). Although changes in physiological performance should be relatively easy to identify, observations for multiple species have only been reported for one MHW and only for turfforming seaweeds as well as one kelp. During the 1982/83 El Niño in California, changes in coloration from red to unusually green were evident for Porphyra perforata, Iridaea cordata, Laurencia spectabilis, Prionitis lanceolata, Gastroclonium subarticulatum, and Gigartina canaliculata near Point Piedras 


\begin{tabular}{|c|c|c|c|c|}
\hline \multicolumn{2}{|c|}{ Response Group } & \multirow{2}{*}{$\begin{array}{l}\text { Response } \\
\text { Not } \\
\text { detected }\end{array}$} & \multirow[t]{2}{*}{ Examples } & \multirow{2}{*}{$\begin{array}{l}\text { MHW } \\
2011 \text { Ningaloo Niño, WA } \\
\text { (Hamelin Bay) } \\
\text { 2013/14 the blob, Southern } \\
\text { California }\end{array}$} \\
\hline & 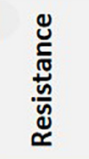 & & & \\
\hline & $\begin{array}{l}\frac{5}{\frac{ \pm}{\pi}} \\
\frac{\stackrel{0}{1}}{1}\end{array}$ & Bleaching & 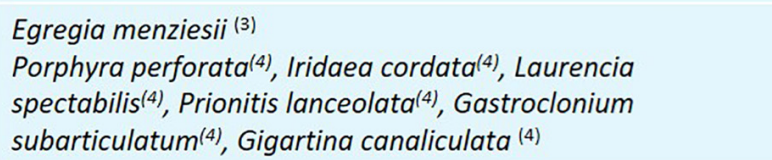 & $\begin{array}{l}\text { 1982/83 ENSO } \\
\text { California }\end{array}$ \\
\hline & \multirow{2}{*}{ 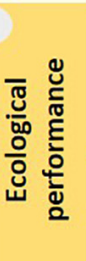 } & $\begin{array}{l}\text { Increased } \\
\text { recruitment } \\
\text { potential }\end{array}$ & Pelvetia fastigiata(3), Sargassum muticum (3) & $\begin{array}{l}\text { 1982/83 ENSO } \\
\text { California }\end{array}$ \\
\hline & & $\begin{array}{l}\text { Increased } \\
\text { herbivory }\end{array}$ & Range-expansion of sub-tropical and tropical herbivores $(5,10)$ & $\begin{array}{l}\text { 1997/98 ENSO } \\
2011 \text { Ningaloo Niño; WA }\end{array}$ \\
\hline & \multirow{3}{*}{ 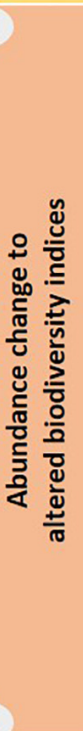 } & $\begin{array}{l}\text { Increased } \\
\text { abundance } \\
\text { natives }\end{array}$ & $\begin{array}{l}\text { Ulva spp. } .^{(2)} \text {, Enteromorpha spp. } .^{(2)} \text {, Iridaea spp. }{ }^{(2)} \\
\text { Geniculate coralline algae }{ }^{(8 ; 9)} \\
\text { CCA }^{(4)} \text { and turf-algae cover }{ }^{(7-10 ; 13 ; 15)} \\
\text { Chorda filum }^{(14)}\end{array}$ & $\begin{array}{l}\text { 1982/83 ENSO, Chile } \\
\text { 2009/10 ENSO, California } \\
2011 \text { Ningaloo Niño; WA }\end{array}$ \\
\hline & & $\begin{array}{l}\text { Increased } \\
\text { abundance } \\
\text { invasives }\end{array}$ & 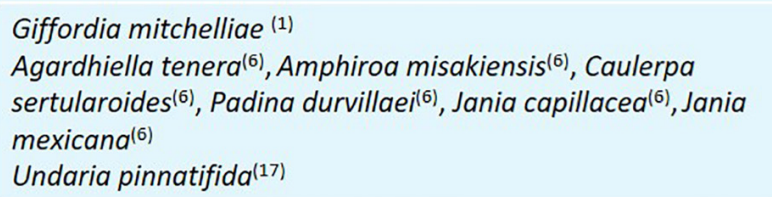 & $\begin{array}{l}\text { 1982/83 ENSO; South } \\
\text { America } \\
\text { 1997/98 ENSO, Mexico } \\
\text { 2017/18 Tasman Sea MHW }\end{array}$ \\
\hline & & $\begin{array}{l}\text { Declined } \\
\text { abundance } \\
\text { natives }\end{array}$ & 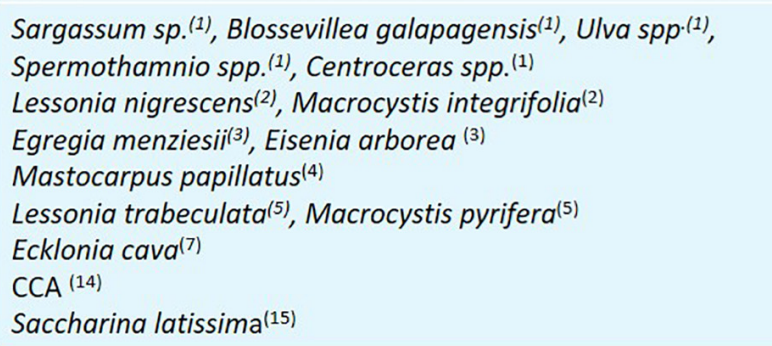 & $\begin{array}{l}\text { 1982/83 ENSO; South } \\
\text { America } \\
\text { 1982/83 ENSO; Chile } \\
\text { 1982/83 ENSO; California } \\
\text { 1997/98 ENSO; Chile } \\
\text { 2011 Ningaloo Niño; WA } \\
\text { 1997, 2002, 2006 hot } \\
\text { summers, Norway }\end{array}$ \\
\hline \multirow[t]{2}{*}{ ஸे } & \multirow{2}{*}{ 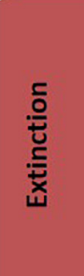 } & $\begin{array}{l}\text { Range shift, } \\
\text { local to } \\
\text { regional } \\
\text { extinction }\end{array}$ & $\begin{array}{l}\text { Ecklonia radiata }^{(10,11)}, \text { Scytothalia dorycarpa } \\
\left.\text { Macrocystis pyrifera }^{(10)}, 11\right) \\
\text { Durvillaea poha }^{(17)}\end{array}$ & $\begin{array}{l}2011 \text { Ningaloo Niño; WA } \\
\text { 2015/16 Tasmanian MHW } \\
\text { 2017/18 Tasman Sea MHW }\end{array}$ \\
\hline & & $\begin{array}{l}\text { Global } \\
\text { extinction }\end{array}$ & Not yet observed & \\
\hline
\end{tabular}

FIGURE 1 | Schematic of different responses of seaweeds with examples to MHWs grouped by severity of the observed response, from no observed effect (e.g., resistance) and less severe impact (e.g., tissue bleaching) at the top, to more severe impacts (e.g., local to global extinctions) at the bottom. Number/letter in brackets refer to Table 1. Several species have multiple observations as their responses differed between locations, e.g., resistance, abundance decline, and regional extinction were observed for Ecklonia radiata and Scytothalia dorycarpa along the latitudinal gradient in Western Australia.

(Murray and Horn, 1989) and at La Jolla many adult individuals of the kelp Egregia menziesii became reddish due to stress (Gunnill, 1985).

\section{Ecological Performance}

Reproduction potential and early life-history stages of many seaweeds are temperature-sensitive (Bartsch et al., 2013;
Andrews et al., 2014), and increased temperatures can both suppress or enhance reproduction and recruitment success (de Bettignies et al., 2018; Muth et al., 2019). Following the 1982/83 El Niño, the turf-forming Pelvetia fastigiata and the canopy-forming fucoid Sargassum muticum showed increased recruitment success at La Jolla, California (Gunnill, 1985), which led to elevated abundances and likely shifted competitiveness 
TABLE 1 | Details of studies ( $n=20 ; 17$ journal articles ${ }^{1-17}$, three news articles $\left.{ }^{a, b, c}\right)$ and species/genera $(n=58)$ found with recorded impacts of MHWs on algae.

\begin{tabular}{|c|c|c|c|c|c|}
\hline MHW & Species & Classification & Functional group & Study number & References \\
\hline $\begin{array}{l}\text { 1982/83 ENSO } \\
\text { South America }\end{array}$ & $\begin{array}{l}\text { Sargassum sp. } \\
\text { Blossevillea galapagensis } \\
\text { Ulva spp. } \\
\text { Spermothamnio spp. } \\
\text { Centroceras spp. } \\
\text { Giffordia mitchelliae }\end{array}$ & $\begin{array}{l}\text { Phaeophyceae } \\
\text { Phaeophyceae } \\
\text { Chlorophyta } \\
\text { Rhodophyta } \\
\text { Rhodophyta } \\
\text { Phaeophyceae }\end{array}$ & $\begin{array}{l}\text { Canopy } \\
\text { Canopy } \\
\text { Turf } \\
\text { Turf } \\
\text { Turf } \\
\text { Turf }\end{array}$ & 1 & Laurie, 1990 \\
\hline $\begin{array}{l}\text { 1982/83 ENSO } \\
\text { Chile }\end{array}$ & $\begin{array}{l}\text { Lessonia nigrescens } \\
\text { Macrocystis pyrifera } \\
\text { Ulva spp. } \\
\text { Enteromorpha spp. } \\
\text { Iridaea spp. }\end{array}$ & $\begin{array}{l}\text { Phaeophyceae } \\
\text { Phaeophyceae } \\
\text { Chlorophyta } \\
\text { Chlorophyta } \\
\text { Rhodophyta }\end{array}$ & $\begin{array}{l}\text { Canopy } \\
\text { Canopy } \\
\text { Turf } \\
\text { Turf } \\
\text { Turf }\end{array}$ & 2 & Soto, 1985 \\
\hline $\begin{array}{l}\text { 1982/83 ENSO } \\
\text { California }\end{array}$ & $\begin{array}{l}\text { Egregia menziesii } \\
\text { Ecklonia arborea } \\
\text { Pelvetia fastigiata } \\
\text { Sargassum muticum }\end{array}$ & $\begin{array}{l}\text { Phaeophyceae } \\
\text { Phaeophyceae } \\
\text { Phaeophyceae } \\
\text { Phaeophyceae }\end{array}$ & $\begin{array}{l}\text { Canopy } \\
\text { Canopy } \\
\text { Turf } \\
\text { Canopy }\end{array}$ & 3 & Gunnill, 1985 \\
\hline $\begin{array}{l}\text { 1982/83 ENSO } \\
\text { California } \\
\text { (Piedras Blancas) }\end{array}$ & $\begin{array}{l}\text { Porphyra perforata } \\
\text { Iridaea cordata } \\
\text { Laurencia spectabilis } \\
\text { Prionitis lanceolata } \\
\text { Gastroclonium } \\
\text { subarticulatum } \\
\text { Gigartina canaliculata } \\
\text { CCA } \\
\text { Mastocarpus papillatus }\end{array}$ & $\begin{array}{l}\text { Rhodophyta } \\
\text { Rhodophyta } \\
\text { Rhodophyta } \\
\text { Rhodophyta } \\
\text { Rhodophyta } \\
\text { Rhodophyta } \\
\text { CCA } \\
\text { Rhodophyta }\end{array}$ & $\begin{array}{l}\text { Turf } \\
\text { Turf } \\
\text { Turf } \\
\text { Turf } \\
\text { Turf } \\
\text { Turf } \\
\text { Crust } \\
\text { Turf }\end{array}$ & 4 & Murray and Horn, 1989 \\
\hline $\begin{array}{l}\text { 1997/98 ENSO } \\
\text { Chile }\end{array}$ & $\begin{array}{l}\text { Macrocystis pyrifera } \\
\text { Lessonia trabeculata }\end{array}$ & $\begin{array}{l}\text { Phaeophyceae } \\
\text { Phaeophyceae }\end{array}$ & $\begin{array}{l}\text { Canopy } \\
\text { Canopy }\end{array}$ & 5 & Alonso Vega et al., 2005 \\
\hline $\begin{array}{l}\text { 1997/98 ENSO } \\
\text { Pacific Mexican Coast }\end{array}$ & $\begin{array}{l}\text { Agardhiella tenera } \\
\text { Amphiroa misakiensis } \\
\text { Caulerpa sertularoides } \\
\text { Padina durvillaei } \\
\text { Jania capillacea } \\
\text { Jania mexicana }\end{array}$ & $\begin{array}{l}\text { Rhodophyta } \\
\text { Rhodophyta } \\
\text { Chlorophyta } \\
\text { Phaeophyceae } \\
\text { Rhodophyta } \\
\text { Rhodophyta }\end{array}$ & $\begin{array}{l}\text { Turf } \\
\text { Turf } \\
\text { Turf } \\
\text { Turf } \\
\text { Turf } \\
\text { Turf }\end{array}$ & 6 & Carballo et al., 2002 \\
\hline $\begin{array}{l}\text { 1997/1998 ENSO } \\
\text { southern Japan }\end{array}$ & $\begin{array}{l}\text { Ecklonia cava } \\
\text { GCA }\end{array}$ & $\begin{array}{l}\text { Phaeophyceae } \\
\text { Rhodophyta }\end{array}$ & $\begin{array}{l}\text { Canopy } \\
\text { Turf }\end{array}$ & $\begin{array}{l}7 \\
8\end{array}$ & $\begin{array}{l}\text { Serisawa et al., } 2004 \\
\text { Tanaka et al., } 2012\end{array}$ \\
\hline $\begin{array}{l}\text { 2009/10 ENSO } \\
\text { Southern Mexican Pacific }\end{array}$ & $\begin{array}{l}\text { Turf-forming algae } \\
\text { GCA (Amphiroa) }\end{array}$ & $\begin{array}{l}\text { Turf } \\
\text { Rhodophyta }\end{array}$ & $\begin{array}{l}\text { Turf } \\
\text { Turf }\end{array}$ & 9 & López-Pérez et al., 2016 \\
\hline $\begin{array}{l}2011 \text { Ningaloo Niño } \\
\text { Western Australia }\end{array}$ & $\begin{array}{l}\text { Ecklonia radiata } \\
\text { Scytothalia dorycarpa } \\
\text { Turf-forming algae } \\
\text { CCA } \\
\text { CCA biofouling (on E. radiata) }\end{array}$ & $\begin{array}{l}\text { Phaeophyceae } \\
\text { Phaeophyceae } \\
\text { Turf } \\
\text { CCA } \\
\text { CCA }\end{array}$ & $\begin{array}{l}\text { Canopy } \\
\text { Canopy } \\
\text { Turf } \\
\text { Crust } \\
\text { Crust }\end{array}$ & $\begin{array}{l}10 \\
11 \\
12 \\
13\end{array}$ & $\begin{array}{l}\text { Wernberg et al., } 2016 \\
\text { Smale and Wernberg, } 2013 \\
\text { Wernberg et al., 2013a } \\
\text { Smale and Wernberg, } 2012\end{array}$ \\
\hline $\begin{array}{l}2011 \text { Ningaloo Niño } \\
\text { Western Australia }\end{array}$ & CCA & CCA & Crust & 14 & Short et al., 2015 \\
\hline $\begin{array}{l}\text { 1997, 2002, } 2006 \text { hot } \\
\text { summers }\end{array}$ & $\begin{array}{l}\text { Saccharina latissima } \\
\text { Turf-forming algae } \\
\text { Chorda filum }\end{array}$ & $\begin{array}{l}\text { Phaeophyceae } \\
\text { Turf } \\
\text { Phaeophyceae }\end{array}$ & $\begin{array}{l}\text { Canopy } \\
\text { Turf } \\
\text { Canopy }\end{array}$ & 15 & Moy and Christie, 2012 \\
\hline $\begin{array}{l}2013 / 14 \text { the blob followed } \\
\text { by } 2015 / 16 \text { ENSO } \\
\text { Southern California }\end{array}$ & $\begin{array}{l}\text { Macrocystis pyrifera } \\
\text { understory algae }\end{array}$ & $\begin{array}{l}\text { Phaeophyceae } \\
\text { Turf }\end{array}$ & $\begin{array}{l}\text { Canopy } \\
\text { Turf }\end{array}$ & 16 & Reed et al., 2016 \\
\hline $\begin{array}{l}\text { 2017/18 Tasman Sea MHW } \\
\text { Christchurch, NZ }\end{array}$ & $\begin{array}{l}\text { Durvillaea spp. } \\
\text { Undaria pinnatifida } \\
\text { Colpomenia sinuosa } \\
\text { Dictyota sp. }\end{array}$ & $\begin{array}{l}\text { Phaeophyceae } \\
\text { Phaeophyceae } \\
\text { Phaeophyceae } \\
\text { Phaeophyceae }\end{array}$ & $\begin{array}{l}\text { Canopy } \\
\text { Canopy } \\
\text { Turf } \\
\text { Turf }\end{array}$ & 17 & Thomsen et al., 2019 \\
\hline $\begin{array}{l}2013 / 14 \text { the blob followed } \\
\text { by } 2015 / 16 \text { ENSO } \\
\text { Philippines }\end{array}$ & Seaweed production drop & & & a & Galolo, 2016 \\
\hline $\begin{array}{l}2013 / 14 \text { the blob followed } \\
\text { by } 2015 / 16 \text { ENSO } \\
\text { Northern California }\end{array}$ & Nereocystis luetkeana & Phaeophyceae & Canopy & $b$ & Catton, 2016 \\
\hline 2015/16 Tasmanian MHW & Macrocystis pyrifera & Phaeophyceae & Canopy & $\mathrm{C}$ & Mathiesen, 2016 \\
\hline
\end{tabular}

News articles were only included if results were not yet published in peer-reviewed journals. MHW, marine heatwave, CCA, crustose coralline algae, GCA, geniculate coralline algae, ENSO, El Niño Southern Oscillation. Effects are recorded in Figure 1. 


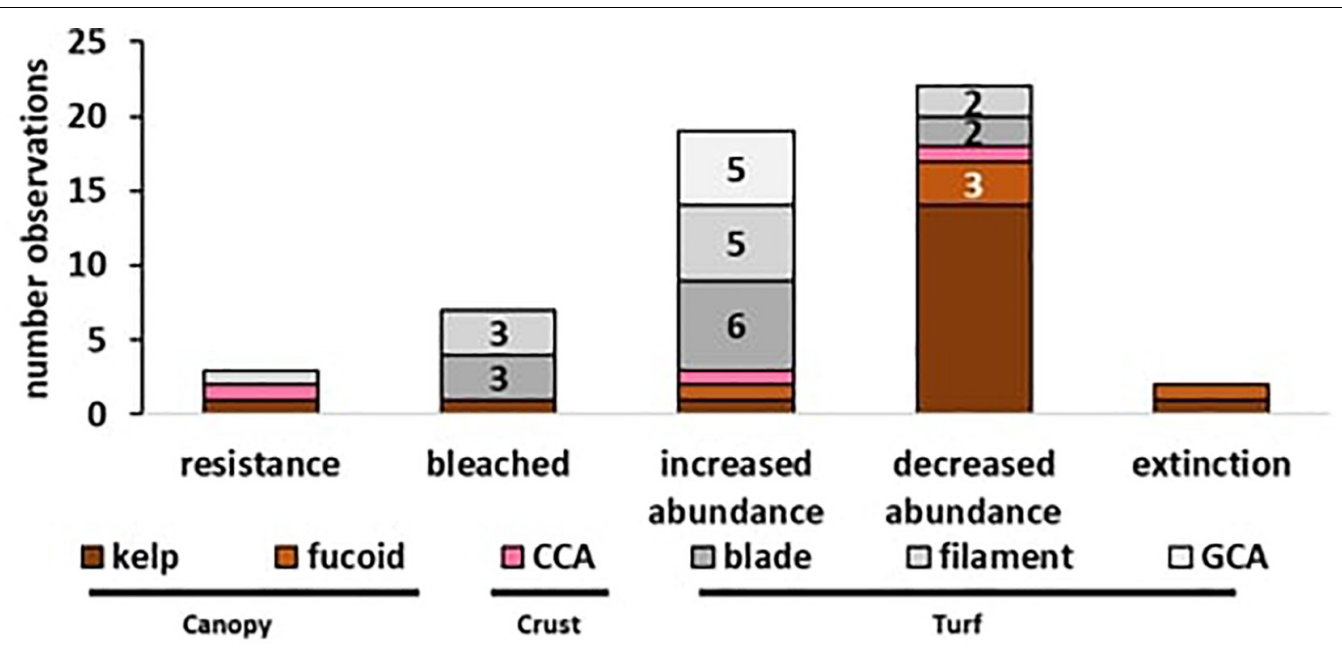

FIGURE 2 | Effects of MHWs on seaweeds ( $n=58$ observations): Reported observations ranging from resistance, over bleaching, abundance changes (increase/decreased) to local extinction. Color coding represents the functional groups with (i) canopy (brown), (ii) crust (pink), and (iii) turfs (gray). Numbers represent count of observations where $n \geq 2$, no number represents a single observation.

between species. Furthermore, grazing pressure on seaweeds is likely increased when tropical and subtropical herbivores shift their ranges (Vergés et al., 2014a; Smale et al., 2017; Zarco-Perello et al., 2017) due to MHWs. Altered grazing pressure can result in the collapse of seaweed populations and reinforcement of ecosystem transitions (Haraguchi et al., 2009; Vergés et al., 2014a,b, 2016; Bennett et al., 2015b; Franco et al., 2015). During the $1997 / 98$ El Niño, an increase in grazing pressure occurred simultaneously at lower latitudes $\left(10-23^{\circ} \mathrm{S}\right)$ of both hemispheres, and the combination of thermal anomalies and migration of grazers produced a synergistic effect. In northern Chile, two canopy-forming kelps were negatively affected, with local disappearance of Macrocystis pyrifera at shallow depths and a decreased abundance of Lessonia trabeculata at its depth limit (Halpin et al., 2004; Alonso Vega et al., 2005). During the following 1998-2000 La Niña event, kelp productivity was minimal due local disappearance of $M$. pyrifera and decreased densities of $L$. trabeculata, however, recovery occurred post La Niña during the mild 2002/03 El Niño event (Alonso Vega et al., 2005).

In Western Australia, the 2010/11 MHW led to increased herbivory due to the range expansion of tropical and subtropical herbivores, reinforcing the temperature-driven loss of the kelp Ecklonia radiata, and facilitating domination of turf algae, with no signs of recovery 8 years after the event (Wernberg, 2019). Additionally, tropical herbivorous fish expanded their range beyond the areas directly affected by the high $\mathrm{MHW}$ temperatures, resulting in a further decline of seaweed canopy cover by up to $\sim 70 \%$ at localized reefs (Zarco-Perello et al., 2017). This MHW also caused heavy biofouling by CCA on E. radiata at the Houtman Abrolhos Islands in Western Australia (Smale and Wernberg, 2012), the only report of its kind to date. Thus, indirect effects of MHWs come in an array of forms and can act as important drivers of change within marine systems, with possible long-lasting impacts far beyond the direct MHW impacts itself.

\section{Changes in Abundance}

The most commonly recorded effect of MHWs was changes in seaweed abundances ( $\sim 79 \%$ of all observations). During the extreme 1982/83 El Niño, areas of the Galapagos archipelago in South America experienced declines of fucoids and turfforming seaweeds, followed by colonization of the invasive turfforming seaweed Giffordia mitchelliae. The fucoids Sargassum sp. and Blossevillea galapagensis as well as the turfs Ulva spp., Spermothamnio spp. and Centroceras spp. decreased in abundance (Laurie, 1990). In comparison, the same ENSO event led to reduced abundances of the two kelps Lessonia nigrescens and Macrocystis pyrifera in Chile (Soto, 1985). After the abundance of kelp was reduced, the turf-forming seaweeds Ulva, Enteromorpha and Iridaea spp. all proliferated (Soto, 1985). In California, the ENSO-associated warming event resulted in no drastic changes, but led to reduced abundances of the kelps Egregia menziesii and Ecklonia arborea at La Jolla (Gunnill, 1985), and a substantial increase of CCA in the low- and midintertidal zone near Point Piedras Blancas (Murray and Horn, 1989). Even though there is some uncertainty attributing the effects in California to the warmer sea temperatures per se due to the co-occurrence of large waves, the population-level responses were similar to those that occurred due to elevated water temperatures recorded in late summer and autumn of 1976 (Gunnill, 1985).

During the 1997/98 El Niño in northern Chile kelp abundances were maintained due to the continuity of coastal upwelling buffering the warming of the ocean. However, after the 1997/98 El Niño event two kelp species were negatively affected with complete disappearance of $M$. pyrifera at shallow depths and decreased abundance of Lessonia trabeculata (Alonso Vega et al., 2005). Along the Pacific Mexican Coast seaweed diversity and biomass fluctuated significantly, with an initial increase in biomass caused by the rise in the abundance of warm water tolerant species such as the small turf species 
Agardhiella tenera, Amphiroa misakiensis, Caulerpa sertularoides, Padina durvillaei, Jania capillacea, and Jania mexicana (Carballo et al., 2002). Overall, seaweed diversity decreased and net biomass increased during the ENSO, whereas diversity increased, biomass decreased and the assemblage structure were altered following the El Niño mediated MHW (Carballo et al., 2002), highlighting the complexity of impacts that MHWs exert over seaweed communities. In the southern Mexican Pacific coral reef communities, the 2009/10 ENSO increased seaweed cover from 2 to $6 \%$ due to an increase in turf-forming algae (López-Pérez et al., 2016). This increase in seaweed cover was coupled with a decrease in coral cover, coral overgrowth and changes in echinoderm and fish species composition, all of which altered the overall reef community (López-Pérez et al., 2016). Significant increases of turf-forming algae also occurred in southwestern Australia following the 2010/11 MHW, after drastic declines and range-contractions of canopy forming seaweeds (E. radiata and Scytothalia dorycarpa) at their northern range edge (Smale and Wernberg, 2013; Wernberg et al., 2013a, 2016). The same MHW in Western Australia negatively affected CCA, suppressing seasonal growth patterns and increasing mortality rates (Short et al., 2015). In comparison, a shift toward CCA dominated barrens followed widespread loss of seaweed forests (Ecklonia cava) in Japan after the 1997/98 ENSO and particularly poor growth of E. cava in 1999 and 2001 (Serisawa et al., 2004; Tanaka et al., 2012). Also, the 2017/18 Tasmanian Sea MHW resulted in midrange extinctions and declines in abundances of bull kelp, Durvillaea spp. while the percent cover of the weedy macroalgae Undaria pinnatifida, Colpomenia sinuosa and Dictyota sp. increased in conjunction, most likely due to competitive release (Thomsen et al., 2019).

Overall, we found 22 records both of increased and decreased abundances of seaweeds as a result of MHW events. All 22 records for abundance declines were native species, whereas from the 22 abundance increases reported, 13 were native species and nine were invasive species. Given the fact that invasive species generally have broader temperature tolerances than native species (Sorte et al., 2010) these numbers suggest that the occurrence of MHW events could increase the competitiveness of invasive species.

Interesting differences were also found between growth forms, as 14 records reported a decrease in the abundance of canopyforming kelps and three reported that fucoids experienced a decline in abundance (see Figure 2). For turf-forming species, only one record showed decline in two native turfs, but an invasive turf increased in abundance. In contrast, 18 observations report the increase of turf-forming bladed, filamentous or geniculate coralline algae (GCA). For CCA, no clear trend was obvious, as over four records CCA responses were ranging from resistance to increased abundance, increased abundance as biofouling but also increased mortality. Overall, large conspicuous canopy-formers generally declined following a MHW, whereas for CCA no clear pattern was evident due to a low number of observation, and for turf-forming seaweeds several cases of decreased abundances were observed, but the majority of records showed an increase in abundance.

\section{Local and Regional Extinctions}

While changes in abundance have been recorded for several species in response to multiple MHWs, only in one instance have regional extinctions along the range edge been observed. The 2010/11 MHW off Western Australia led to a poleward range contraction of $\sim 100 \mathrm{~km}$ for two of the main canopyforming seaweeds, Ecklonia radiata and Scytothalia dorycarpa, as marginal populations were extirpated (Smale and Wernberg, 2013; Wernberg et al., 2013a). This contraction culminated in the loss of $43 \%$ of the marine forests along $>800 \mathrm{~km}$ of coastline, and a regime shift toward turf-dominated reefs (Wernberg et al., 2016; Filbee-Dexter and Wernberg, 2018; Wernberg, 2019). Besides extinctions at the trailing range edge, local extinctions of rangecenter populations have also been observed. The 2015/16 Tasman Sea MHW was associated with localized die-off of Macrocystis pyrifera off Tasmania's east coast (Mathiesen, 2016). Over the last few decades, $M$. pyrifera has declined from a $250 \mathrm{~km}$ stretch along Tasmania's eastcoast to a last remaining patch in the inner coves of Munroe Bight (Mathiesen, 2016). The 2015/16 Tasmanian MHW, however, stressed M. pyrifera individuals which became less resilient to winter storms and were dislodged from the inner coves of Munroe Bight, leading to a local as well as regional extinction of this species along the eastern Tasmanian coast (Mathiesen, 2016). Additionally, following the Tasman Sea MHW in 2017/18, widespread declines in abundance with mid-range local extinctions of bull kelp were observed on the east coast of the South Island of New Zealand (Thomsen et al., 2019). Regional surveys showed a strong reduction in the abundance of Durvillaea poha in the region and smaller reductions in D. willana. Targeted surveys around Christchurch revealed total elimination of Durvillaea spp. on 12 out of 19 local reefs, with reef-wide extinctions observed on the reefs within and immediately north or south of Lyttelton Harbor (Thomsen et al., 2019). Following the elimination of Durvillaea spp. densities and cover of weedy macroalgae increased in the area previously inhabited by Durvillaea spp. with the potential to suppress future re-colonization by Durvillaea spp. into these areas (Thomsen et al., 2019).

\section{Post-MHW Recovery Potential}

The potential for affected seaweed populations to recover from MHWs will depend on the severity of the MHW and on speciesspecific traits of the seaweeds. This includes the location within a species range, species-specific thermal tolerance and reproductive traits, life history (e.g., annual versus perennial) and dispersal capacities. Additionally, recovery trajectories will depend on the severity of alterations in ecosystem structure and local patterns of oceanic currents.

When seaweed abundance declines in the center or poleward parts of the species' range, there is a high chance for population recovery after the MHW due to local reseeding as well as dispersal from adjacent areas (Figure 3). In contrast, when propagules are unlikely to disperse into affected areas (Molinos et al., 2017), competitive interactions are altered, or grazing pressure increased, recovery is unlikely or will be very slow. In the more extreme case of local extinctions, recovery will likely be markedly slower as it will depend on re-seeding from less 


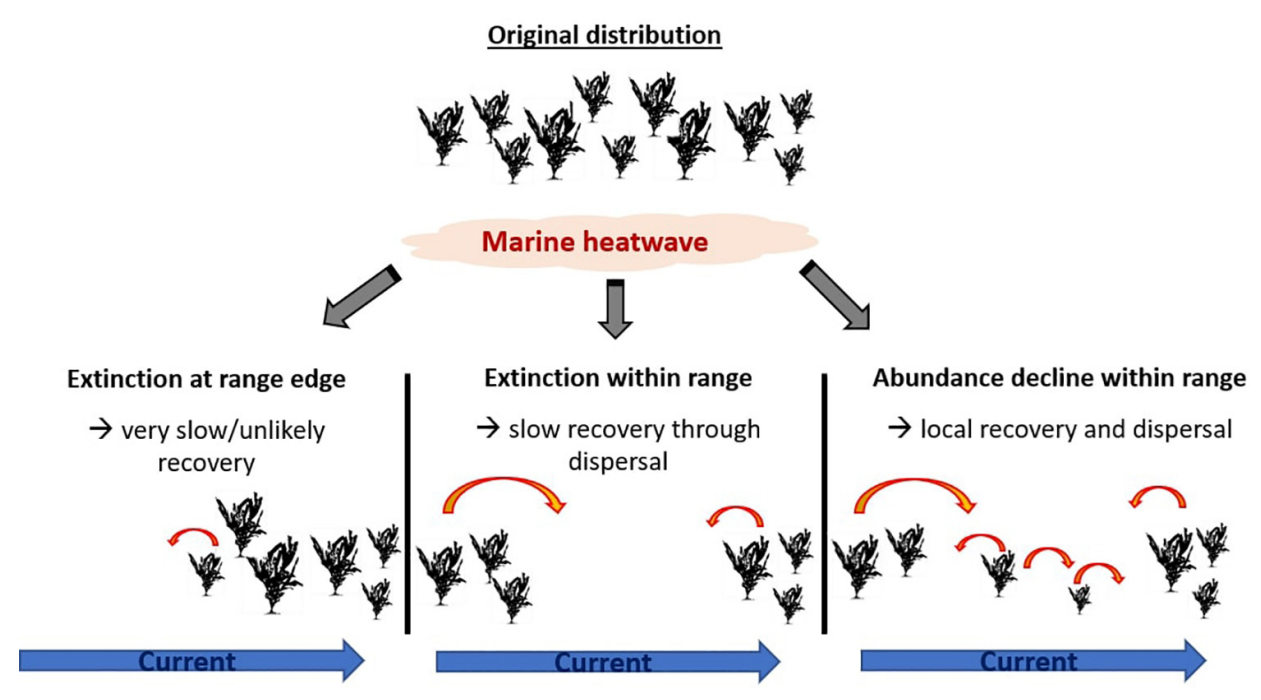

FIGURE 3 | Simplified single-species schematic of recovery possibility after a marine heatwave which resulted in local extinction at equatorward range edge, local extinction within distributional range and abundance decrease within distributional range. Red errors stand for dispersal, with decreased dispersal likelihood for smaller arrows.

affected populations, which may be separated by considerable distances. In the extreme case of localized to regional extinctions at the equatorward range edge of a species, recovery is predicted to be very slow or unlikely to occur. The 2010/11 MHW in Western Australia demonstrates how recovery is unlikely after extinctions along the range edge. To date, the marine forests that were lost have not recovered (Wernberg et al., 2016; Wernberg, 2019) and the poleward flow of the Leeuwin Current makes natural re-seeding unlikely, as possible source populations are located "downstream." Additionally, recovery will depend on herbivore pressure, as range-expanded as well as local herbivores may suppress any recovery and facilitate domination by turf algae (Bennett et al., 2015b; Wernberg et al., 2016; Filbee-Dexter and Wernberg, 2018).

In all cases, recovery potential is dependent on a return to suitable conditions (e.g., temperature, light, turbidity) after the MHW, competition for space (open settlement ground, species invasions) and herbivore pressure, and the distance from adjacent populations, dispersal properties and current systems (Molinos et al., 2015) for reseeding success. However, it is unlikely that a complete recovery to pre-event conditions will occur, as postdisturbance communities are generally different from the predisturbed communities (Sousa, 1984; Shea et al., 2004), resulting in different ecosystem structure and function. Ultimately, declines in abundance and localized extinctions within a species range may be the precursor to projected future range contractions at a species distributional limit (Martinez et al., 2018).

\section{Attribution of Impacts to MHWs}

A large proportion of the observed impacts were directly attributed to the events with extreme temperatures identified as the main or one of the key drivers of documented impacts (16 of the 19 studies). Only three studies (Gunnill, 1985; Moy and Christie, 2012; Reed et al., 2016) did not attribute changes in seaweed performance majorly to MHWs due to the co-occurrence of interacting processes, making it difficult to disentangle the influence of each driver. In these instances, the MHWs were accompanied by storms and long-term eutrophication, or previous impacts in the area surpassed possible MHW effects (e.g., recruitment peaks in prior years, great annual variability). For example, the lack of dramatic long-term effects on seaweeds of the 1982/83 MHW in California is likely to be a consequence of strong storms and high cloud cover which reduced desiccation stress and buffered the possibly negative temperature effects (Gunnill, 1985). Furthermore, seaweed increased in abundance prior to the MHW through recruitment peaks in 1977, 1981, and 1982. As a result, seaweeds persisted during the event (Gunnill, 1985). However, it is likely that the MHW weakened the seaweeds and contributed to the severe loss during storms and strong wave action following the event (Gunnill, 1985). Similarly, multiple stressors, e.g., warm summer temperature, eutrophication and increased sedimentation have been suggested to explain ecosystem shifts in Norway, with large-scale shifts from sugar kelp forests (Saccharina latissima) to filamentous red algae on the Skagerrak coast and shifts to a small, functionally different kelp, Chorda filum, on the west coast (Moy and Christie, 2012). While the study was not designed to identify the causes of change, severe long-term eutrophication accompanied by reduced light levels was inferred to be the main driver explaining the loss of S. latissima. One possible trigger identified for the sudden community shifts were the unusually hot summers in 1997, 2002 and 2006 for 58, 36, and 45 days, respectively, which resulted in SSTs exceeding the thermal tolerance of S. latissima (Moy and Christie, 2012). Thus, it is often complicated to establish causal linkages to MHWs as multiple drivers typically occur simultaneously, resulting in complex interactive effects with studies not designed to disentangle possible drivers and 
their contributions (Moy and Christie, 2012; Filbee-Dexter and Wernberg, 2018).

It is possible that the effects of MHWs may not be evident during, or immediately after the peaks in temperature, but instead have long time-lags. For example, in California, following the MHW in 1982/83, significant differences in seaweed abundance and diversity were evident in the winter of 1983/84 (Gunnill, 1985). It is possible that standing stocks of the two laminarians Ecklonia arborea and Egregia menziesii decreased as the MHW weakened the plants resulting in delayed die-offs during the summer of 1983 (Gunnill, 1985). The impact of MHWs can also vary between geographical region. This was observed following the 1997/98 El Niño which caused local extinctions of the kelp Macrocystis pyrifera in Peru, southern Chile and California, whereas effects in Japan and northern Chile were delayed and only detected after the event (Edwards, 2004). Similarly, in Western Australia impacts of the 2010/11 MHW ranged from catastrophic for marine temperate communities at warmer locations (Kalbarri, $28^{\circ} \mathrm{S}$ ), severe in central locations (Jurien Bay, $30^{\circ} \mathrm{S}$ ) to absent in cooler locations (Hamelin Bay, $34^{\circ} \mathrm{S}$ ), even though all regions experienced similar temperature anomalies (Wernberg et al., 2013a, 2016, 2018a). Delayed impacts and differential responses over time (season) and space, is likely to depend on the spatial extent and magnitude of the MHW as well as species-specific geographical ranges and potential for local adaptation (Wernberg et al., 2018a), and may cause MHWs to go unrecognized as important drivers of ecological change.

\section{Limitations}

The majority of published information on seaweed responses to MHWs are from sites that were subjected to extreme warming conditions and experienced a multitude of ecological impacts. Notwithstanding potential publication bias that encourage reporting significant ecological changes following MHWs, but discourage reports about species resistance (no changes, i.e., nonsignificant effects), lack of observed impacts at some sites may be the result of limited seaweed research taking place or difficulties in determining impacts due to a lack of long-term baseline data or high natural inter-annual variability. For example, $M$. pyrifera in California showed considerable biomass variation between 2001 and 2015. Although the recorded M. pyrifera biomass in 2014 and 15 during and directly after "the blob" were two of the lowest on record, the low biomass was not attributed to the MHW because its biomass is naturally variable and the monitoring sites were well within the species distribution range (Reed et al., 2016). The importance of biogeography was also evident during the 2010/11 MHW in Western Australia, where the more southern (Hamelin Bay, cool region) populations of E. radiata, CCA and turfforming algae showed resistance, whereas northern populations closer to the trailing range edge (Jurien Bay, warm region) were heavily impacted by the MHW despite experiencing similar temperature anomalies (Wernberg et al., 2013a). These different responses at two locations within the area covered by the MHW highlights the need to consider the location of a population within a species range as well as species-specific thermal limits and the potential of resistance when assessing impacts from MHWs (Wernberg et al., 2013a, 2016). Moreover, recent evidence suggests that thermal divergence, either via plasticity or adaptation, is common across species distributional ranges in marine macrophytes (King et al., 2017). Range-center seaweed populations could therefore be equally vulnerable to MHWs compared to range-edge populations (Bennett et al., 2015a; King et al., 2019; Thomsen et al., 2019); clearly, further work on intraspecific and inter-regional variability in susceptibility to MHWs is warranted (Bennett et al., 2019).

A key constraint of MHW impact studies is the lack of available historical information about seaweed populations and communities - a prerequisite to disentangle impacts from natural variability and to quantify the magnitude of ecological change (Southward et al., 1995; Wernberg et al., 2016). Without historical baseline data it is particularly difficult to detect resistance as well as immediate to long-term changes, and dramatic largescale impacts have only been recognized in areas with sustained biological monitoring (Wernberg et al., 2011b; Poloczanska et al., 2013). This limitation can, however, be ameliorated, to an extent, by combining observations with MHW experimental studies. As climate change experimental studies on seaweed are still rare (Wernberg et al., 2012), and even more scarce related to MHWs (Gouvea et al., 2017), we recommend that efforts are directed toward conducting such experiments. Focus should be first on determining susceptibility of key species to different characteristics of MHWs, followed by studies disentangling the interactive nature of temperature, desiccation, solar radiation and eutrophication effect to determine when and if stressors enhance or buffer against impacts of each other. Additionally, we emphasize the invaluable knowledge that baseline data on seaweed biogeography, population structure and physiological performances can provide, both to document and assess future impacts as well as re-analyzing existing datasets to evaluate in more detail resistance and susceptibility of seaweeds to MHWs as well as assess which additional factors could have enhanced or buffered temperature effects.

\section{CONCLUSION}

Superimposed on decadal-scale increases in mean oceanic temperatures, MHWs are increasing in frequency and duration (Oliver et al., 2018), and will likely continue to do so in the future (Frölicher and Laufkötter, 2018). These MHWs have impacted marine ecosystems with well-documented effects on seaweeds ranging from resistance, to altered physiological and ecological performances, and drastic shifts in ecosystem structure and functioning and, in a few cases, regime shifts. These regime shifts have led to profound economic and environmental changes (Wernberg et al., 2016; Filbee-Dexter and Wernberg, 2018; Smale et al., 2019). In addition to directly affecting seaweeds, MHWs have facilitated poleward range shifts of subtropical and tropical herbivores, leading to increased grazing pressure (Bennett et al., 2015b; Vergés et al., 2016; Zarco-Perello et al., 2017). This compounded stress favors a shift from canopy-forming kelps and fucoids toward simplified turf-dominated systems that suppresses canopy recovery. Between canopy-formers, turfs and crustose coralline algae, turf-forming seaweeds were the only functional 
group with a majority of positive responses. Ultimately, the severity of MHW effects will depend on the resilience, recovery and recolonization traits of the affected seaweeds, their position within their thermal safety margins, interaction with other stressors such as eutrophication and altered currents, modified grazing pressure, and the attributes of the MHWs. Specifically, research about the resilience of seaweeds is required to better understand species-specific sensitivity to MHWs, and to identify which coastal regions are most vulnerable to regime shifts. Further range shifts and local regime shifts in marine forests, as well as within similarly important ecosystems (e.g., coral reefs and seagrasses meadows), seem inevitable in the near future (Takao et al., 2015; Kumagai et al., 2018; Martinez et al., 2018; Smale et al., 2019). However, it remains uncertain how altered ecosystems will impact the provision of ecological services upon which human societies depend.

\section{AUTHOR CONTRIBUTIONS}

SS and TW conceived the idea for the manuscript. SS wrote the manuscript. TW, MT, PM, MB, BH, and DS

\section{REFERENCES}

Alonso Vega, J. M., Vásquez, J. A., and Buschmann, A. H. (2005). Population biology of the subtidal kelps Macrocystis integrifolia and Lessonia trabeculata (Laminariales, Phaeophyceae) in an upwelling ecosystem of Northern Chile: interannual variability and el niño 1997-1998. Rev. Chil. Hist. Nat. 78, 33-50.

Andersen, T., Carstensen, J., Hernández-García, E., and Duarte, C. M. (2009). Ecological thresholds and regime shifts: approaches to identification. Trends Ecol. Evol. 24, 49-57. doi: 10.1016/j.tree.2008.07.014

Andrews, S., Bennett, S., and Wernberg, T. (2014). Reproductive seasonality and early life temperature sensitivity reflect vulnerability of a seaweed undergoing range reduction. Mar. Ecol. Prog. Ser. 495, 119-129. doi: 10.3354/meps 10567

Bartsch, I., Vogt, J., Pehlke, C., and Hanelt, D. (2013). Prevailing sea surface temperatures inhibit summer reproduction of the kelp Laminaria digitata at Helgoland (North Sea). J. Phycol. 49, 1061-1073. doi: 10.1111/jpy.12125

Bennett, S., Duarte, C. M., Marba, N., and Wernberg, T. (2019). Integrating withinspecies variation in thermal physiology into climate change ecology. Philos. Trans. R. Soc. B 374:20180550. doi: 10.1098/rstb.2018.0550

Bennett, S., Wernberg, T., Arackal Joy, B., de Bettignies, T., and Campbell, A. H. (2015a). Central and rear-edge populations can be equally vulnerable to warming. Nat. Commun. 6:10280. doi: 10.1038/ncomms 10280

Bennett, S., Wernberg, T., Connell, S. D., Hobday, A. J., Johnson, C. R., and Poloczanska, E. S. (2016). The 'Great Southern Reef': social, ecological and economic value of Australia 's neglected kelp Forests. Mar. Freshw. Res. 67, 47-56.

Bennett, S., Wernberg, T., Harvey, E. S., Santana-Garcon, J., and Saunders, B. J. (2015b). Tropical herbivores provide resilience to a climate-mediated phase shift on temperate Reefs. Ecol. Lett. 18, 714-723. doi: 10.1111/ele. 12450

Bertness, M. D., Leonard, G. H., Levine, J. M., Schmidt, P. R., and Ingraham, A. O. (1999). Testing the relative contribution of positive and negative interactions in rocky intertidal communities. Ecol. Soc. Am. 80, 2711-2726. doi: 10.1890/00129658(1999)080\%5B2711:ttrcop\%5D2.0.co;2

Bond, N. A., Cronin, M. F., Freeland, H., and Mantua, N. (2015). Causes and impacts of the 2014 warm anomaly in the NE Pacific. Geophys. Resear 42, 3414-3420. doi: 10.1002/2015gl063306

Buschbaum, C., Chapman, A. S., and Saier, B. (2006). How an introduced seaweed can affect Epibiota diversity in different coastal systems. Mar. Biol. 148, 743754. doi: 10.1007/s00227-005-0128-9 contributed to the concept and writing. All authors approved the submitted manuscript.

\section{FUNDING}

This contribution is an outcome from the working group "MHWs 2 - Biological implications of heatwaves for marine ecosystems" hosted at the Marine Biological Association of the United Kingdom (Plymouth, United Kingdom) by DS and TW. The working group received support from a University of Western Australia Research Collaboration Award, a UWA School of Plant Biology synthesis grant, a Natural Environment Research Council (United Kingdom) International Opportunity Fund (NE/N00678X/1), and the ARC Centre of Excellence for Climate System Science (ARCCSS). SS was supported by an Australian Government Research Training Program (RTP) Scholarship, TW by ARC grant numbers FT110100174 and DP170100023, DS by NERC IRF NE/K008439/1, PM by a Marie Curie Career Integration Grant (PCIG10-GA-2011-303685) and a Natural Environment Research Council (United Kingdom) Grant (NE/J024082/1), and MT by Brian Mason.

Caputi, N., Kangas, M., Chandrapavan, A., Hart, A., Feng, M., Marin, M., et al. (2019). Factors affecting the recovery of invertebrate stocks from the 2011 Western Australian extreme marine heatwave. Front. Mar. Sci. 6:484. doi: 10. 3389/fmars.2019.00484

Caputi, N., Kangas, M., Denham, A., Feng, M., Pearce, A., Hetzel, Y., et al. (2016). Management adaptation of invertebrate fisheries to an extreme marine heat wave event at a global warming hot spot. Ecol. Evol. 6, 3583-3593. doi: 10.1002/ ece 3.2137

Carballo, L., Olabarria, C., and Osuna, T. G. (2002). Analysis of four macroalgal assemblages along the Pacific Mexican Coast during and after the $1997-98 \mathrm{El}$ Niño. Ecosystems 5, 749-760. doi: 10.1007/s10021-002-0144-2

Casado-Amezúa, P., Araújo, R., Bárbara, I., Bermejo, R., Borja, A., Díez, I., et al. (2019). Distributional shifts of canopy-forming seaweeds from the Atlantic coast of Southern Europe. Biodivers. Conserv. 28, 1151-1172. doi: 10.1007/ s10531-019-01716-9

Catton, C. (2016). 'Perfect Storm' Decimates Northern California Kelp Forests. CDFW Marine Management News. Available at: https://cdfwmarine.wordpress. com/2016/03/30/perfect-storm-decimates-kelp/ (accessed June 20, 2018).

Christensen, J. H., Hewitson, B., Busuioc, A., Chen, A., Gao, X., Held, I., et al. (2007). "Regional climate projections," in Climate Change 2007: The Physical Science Basis. Contribution of Working Group I to the Fourth Assessment Report of the Intergovernmental Panel on Cliamte Change, eds S. Solomon, D. Qin, M. Manning, Z. Chen, M. Marquis, K. Averyt, et al. (Cambridge: Cambridge University Press).

Couch, C. S., Burns, J. H. R., Liu, G., Steward, K., Gutlay, N., Kenyon, J., et al. (2017). Mass coral bleaching due to unprecedented marine heatwave in Papah â Naumoku â kea marine National monument (Northwestern Hawaiian Islands). PLoS One 12:e0185121. doi: 10.1371/journal.pone.0185121

Dayton, P. K. (1985). Ecology of kelp communities. Annu. Rev. Ecol. Syst. 16, 215-245. doi: 10.1146/annurev.ecolsys.16.1.215

Dayton, P. K., and Tegner, M. J. (1983). Catastrophic storms, El Nino, and patch stability in a Southern California kelp community. Science 224, 283-285. doi: $10.1126 /$ science. 224.4646 .283

de Bettignies, T., Wernberg, T., and Gurgel, C. F. (2018). Exploring the influence of temperature on aspects of the reproductive phenology of temperate Seaweeds. Front. Mar. Sci. 5:218. doi: 10.3389/fmars.2018.00218

Edwards, M. S. (2004). Estimating scale-dependency in disturbance impacts: El Niños and giant kelp Forests in the Northeast Pacific. Oecologia 138, 436-447. doi: 10.1007/s00442-003-1452-8 
Egan, S., Fernandes, N. D., Kumar, V., Gardiner, M., and Thomas, T. (2014). Bacterial pathogens, virulence mechanism and host defence in marine macroalgae. Environ. Microbiol. 16, 925-938. doi: 10.1111/1462-2920.12288

Fernandez, C. (2011). The retreat of large brown seaweeds on the North Coast of Spain: the case of Saccorhiza polyschides. Eur. J. Phycol. 46, 352-360. doi: 10.1080/09670262.2011.617840

Filbee-Dexter, K., and Wernberg, T. (2018). Rise of turfs: a new battlefront for globally declining kelp Forests. Bioscience 68, 64-76. doi: 10.1093/biosci/bix147

Franco, J. N., Wernberg, T., Bertocci, I., Duarte, P., Jacinto, D., Vasco-Rodrigues, N., et al. (2015). Herbivory drives kelp recruits into 'hiding' in a warm Ocean climate. Mar. Ecol. Prog. Ser. 536, 1-9. doi: 10.3354/meps 11445

Frölicher, T. L., and Laufkötter, C. (2018). Emerging risks from marine heat waves. Nat. Commun. 9:650. doi: 10.1038/s41467-018-03163-6

Frölicher, T. L., Fischer, E. M., and Gruber, N. (2018). Marine Heatwaves under Global Warming. Nature 560, 360-376. doi: 10.1038/s41586-018-0383-9

Galolo, J. O. (2016). Seaweed Yields Dropped. Available at: http://www.sunstar.com. ph/article/64532/ (accessed January 15, 2018).

Garrabou, J., Coma, R., Bensoussan, N., Bally, M., Chevaldonné, P., Cigliano, M., et al. (2009). Mass mortality in northwestern mediterranean rocky benthic communities: effects of the 2003 heat wave. Glob. Chang. Biol. 15, 1090-1103. doi: 10.1111/j.1365-2486.2008.01823.x

Gaylord, B. P., Rosman, J. H., Reed, D. C., Koseff, J. R., Fram, J., MacIntyre, S., et al. (2007). Spatial patterns of flow and their modification within and around a giant kelp forest. Limnol. Oceanogr. 52, 1838-1852. doi: 10.4319/lo.2007.52.5.1838

Gouvea, L. P., Schubert, N., Leal Martins, C. D., Sissini, M., Ramlov, F., de Oliveira Rodrigues, E. R., et al. (2017). Interactive effects of marine heatwaves and eutrophication on the ecophysiology of a widespread and ecologically important macroalga. Limnol. Oceanogr. 62, 2056-2075. doi: 10.1002/lno.10551

Gunnill, F. F. C. (1985). Population fluctuations of seven macroalgae in Southern California during 1981-1983 including effects of severe storms and an El Nino. J. Exp. Mar. Biol. Ecol. 85, 149-164. doi: 10.1016/0022-0981(85)90140-6

Halpin, P. M., Strub, P. T., Peterson, W. T., and Baumgartner, T. R. (2004). An overview of interactions among oceanography, marine ecosystems, climatic and human disruptions along the Eastern Margins of the Pacific Ocean. Rev. Chil. Hist. Nat. 77, 371-409.

Haraguchi, H., Tanaka, K., Imoto, Z., and Hiraoka, M. (2009). The decline of Ecklonia cava in Kochi, Japan and the challenge in marine afforestation. Kuroshio Sci. 3, 49-54.

Harley, C. D. G., Anderson, K. M., Demes, K. W., Jorve, J. P., Kordas, R. L., Coyle, T. A., et al. (2012). Effects of climate change on global seaweed communities. J. Phycol. 48, 1064-1078. doi: 10.1111/j.1529-8817.2012.01224.x

Hawkins, S. J., and Hartnoll, R. G. (1985). Factors determining the upper limits of intertidal canopy-forming algae. Mar. Ecol. Progr. Ser. 20, 265-271. doi: 10.3354/meps020265

Hobday, A. J., Alexander, L. V., Perkins, S. E., Smale, D. A., Straub, S. C., Oliver, E. C. J., et al. (2016). A hierarchical approach to defining marine heatwaves. Prog. Oceanogr. 141, 227-238. doi: 10.1016/j.pocean.2015.12.014

Hoegh-Guldberg, O., and Bruno, J. F. (2010). The impact of climate change on the world 's marine ecosystems. Science 328, 1523-1528. doi: 10.1126/science. 1189930

Hoegh-Guldberg, O., and Poloczanska, E. S. (2017). Editorial: the effect of climate change across ocean regions. Front. Mar. Sci. 4:361. doi: 10.3389/fmars.2017. 00361

Holbrook, N. J., Scannell, H. A., Sen Gupta, A., Benthuysen, J. A., Feng, M., Oliver, E. C. J., et al. (2018). A global assessment of marine heatwaves and their drivers. Nat. Commun. 10:2624. doi: 10.1038/s41467-019-10206-z

IPCC (2007). Climate Change: The Physical Science Basis. Geneva: IPCC.

King, N. G., McKeown, N. J., Smale, D. A., and Moore, P. J. (2017). The importance of phenotypic plasticity and local adaptation in driving intraspecific variability in thermal niches of marine macrophytes. Ecography 40, 1-14.

King, N. G., Mckeown, N. J., Smale, D. A., Wilcockson, D. C., Hoelters, L., Groves, E. A., et al. (2019). Evidence for different thermal ecotypes in range centre and trailing edge kelp populations. J. Exp. Mar. Biol. Ecol. 51, 10-17. doi: 10.1016/j.jembe.2019.03.004

Kirtman, B., Power, S. B., Adedoyin, J. A., Boer, G. J., Bojaru, R., Camilloni, I., et al. (2013). "Near-term climate change: projections and predictability," in Climate Change 2013: The Physical Science Basis. Contribution of Working Group I to the Fifth Assessment Report of the Intergovernmental Panel on Climate Change, eds T. Stocker, D. Qin, G. Plattner, M. Tignor, S. Allen, J. Boschung, et al. (Cambridge: Cambridge University Press).

Kordas, R. L., Harley, C. D. G., and O'Connor, M. I. (2011). Community ecology in a warming world: the influence of temperature on interspecific interactions in marine systems. J. Exp. Mar. Biol. Ecol. 400, 218-226. doi: 10.1016/j.jembe. 2011.02.029

Krumhansl, K. A., Okamoto, D. K., Rassweiler, A., Novak, M., Bolton, J. J., Cavanaugh, K. C., et al. (2016). Global patterns of kelp forest change over the past Half-Century. PNAS 113, 13785-13790.

Kumagai, N. H., Molinos, J. G., Yamano, H., Takao, S., Fujii, M., and Yamanaka, Y. (2018). Ocean currents and herbivory drive macroalgae-to-coral community shift under climate warming. PNAS 115, 8990-8995. doi: 10.1073/pnas. 1716826115

Laurie, W. A. (1990). Effects of the 1982-83 El Nino-Southern Oscillation Event on Marine Iguana (Amblyrhynchus Cristatus Bell, 1825) Populations on Galapagos (Amsterdam: Elsevier), 361-380.

Le Nohaïc, M., Ross, C. L., Cornwall, C. E., Comeau, S., Lowe, R., McCulloch, M. T., et al. (2017). Marine heatwave causes unprecedented regional mass bleaching of thermally resistant corals in Northwestern Australia. Sci. Rep. 7, 1-11. doi: 10.1038/s41598-017-14794-y

Lima, F. P., and Wethey, D. S. (2012). Three decades of high-resolution coastal sea surface temperatures reveal more than warming. Nat. Commun. 3, 1-13. doi: $10.1038 /$ ncomms1713

Lima, F. P., Ribeiro, P. A., Queiroz, N., Hawkins, S. J., and Santos, A. M. (2007). Do distributional shifts of northern and southern species of algae match the warming pattern? Glob. Chang. Biol. 13, 2592-2604. doi: 10.1111/j.1365-2486. 2007.01451.x

Ling, S. D., Johnson, C. R., Ridgway, K., Hobday, A. J., and Haddon, M. (2009). Climate-driven range extension of a Sea Urchin: inferring future trends by analysis of recent population dynamics. Glob. Chang. Biol. 15, 719-731. doi: 10.1111/j.1365-2486.2008.01734.x

López-Pérez, A., Guendulain-García, S., Granja-Fernández, R., Hernández-Urraca, V., Galván-Rowland, L., Zepeta-Vilchis, R., et al. (2016). Reef community changes associated with the 2009 - 2010 El Niño in the Southern Mexican Pacific Reef. Pac. Sci. 70, 175-190. doi: 10.2984/70.2.4

Madin, E. M. P., Ban, N. C., Doubleday, Z. A., Holmes, T. H., Pecl, G. T., and Smith, F. (2012). Socio-economic and management implications of rangeshifting species in marine systems. Glob. Environ. Chang. 22, 137-146. doi: 10.1016/j.gloenvcha.2011.10.008

Martinez, B., Wernberg, T., Radford, B., Thomsen, M. S., Russell, B. D., Bradshaw, C. J. A., et al. (2018). Distribution Models Predict Large Contractions in Habitat-Forming Seaweeds in Response to Ocean Warming. Divsers. Distribut. 24, 1350-1366. doi: 10.1111/ddi.12767

Marzinelli, E. M., Campbell, A. H., Valdes, E. Z., Vergés, A., Nielsen, S., Wernberg, T., et al. (2015). Continental-scale variation in seaweed host-associated bacterial communities is a function of host condition, not geography. Environ. Microbiol. 17, 4078-4088. doi: 10.1111/1462-2920.12972

Mathiesen, K. (2016). Ocean Heatwave Destroys Tasmania's Unique Underwater Jungle. Kent: Climate Home News.

Mills, K. E., Pershing, A. J., Brown, C. J., Chen, Y., Chiang, F. S., Holland, D. S., et al. (2013). Fisheries management in a changing climate: lessons from the 2012 ocean heat wave in the Northwest Atlantic. Oceanography 26, 191-195.

Molinos, J. G., Burrows, M. T., and Poloczanska, E. S. (2017). Ocean currents modify the coupling between climate change and biogeographical shifts. Sci. Rep. 7, 1-9. doi: 10.1038/s41598-017-01309-y

Molinos, J. G., Halpern, B. S., Schoeman, D. S., Brown, C. J., Kiessling, W., Moore, P. J., et al. (2015). Climate velocity and the future global redistribution of marine biodiversity. Nat. Clim. Chang. 6, 83-88. doi: $10.1111 / \mathrm{gcb}$ 12726

Moy, F. E., and Christie, H. (2012). Large-scale shift from sugar kelp (Saccharina latissima) to ephemeral algae along the South and West Coast of Norway. Mar. Biol. Res. 8, 309-321. doi: 10.1080/17451000.2011. 637561

Murray, S. N., and Horn, M. H. (1989). Variations in standing stocks of Central California macrophytes from a rocky intertidal habitat before and during the 1982-1983 El Nino. Mar. Ecol. Prog. Ser. 58, 113-122. doi: 10.3354/meps05 8113 
Muth, A. F., Graham, M. H., Lane, C. E., and Harley, C. D. G. (2019). Recruitment tolerance to increased temperature present across multiple kelp clades. Ecology 100, 1-7. doi: 10.1002/ecy.2594

O’Brien, J. M., and Scheibling, R. E. (2016). Nipped in the bud: mesograzer feeding preference contributes to kelp decline. Ecology 97, 1873-1886. doi: 10.1890/151728.1

Oliver, E. C. J., Benthuysen, J. A., Bindoff, N. L., Hobday, A. J., Holbrook, N. J., Mundy, C. N., et al. (2017). The unprecedented 2015/16 tasman sea marine heatwave. Nat. Commun. 8, 1-12. doi: 10.1038/ncomms16101

Oliver, E. C. J., Burrows, M. T., Donat, M. G., Gupta, A. S., Alexander, L. V., Perkins-Kirkpatrick, S. E., et al. (2019). Projected marine heatwaves in the 21 st century and the potential for ecological impact. Front. Mar. Sci. 6:734. doi: 10.3389/fmars.2019.00734

Oliver, E. C. J., Donat, M. G., Burrows, M. T., Moore, P. J., Smale, D. A., Alexander, L. V., et al. (2018). Longer and more frequent marine heatwaves over the Past Century. Nat. Commun. 9, 1-12. doi: 10.1038/s41467-018-03732-9

Pearce, A. F., and Feng, M. (2013). The rise and fall of the 'marine heat wave' off Western Australia during the summer of 2010/2011. J. Mar. Syst. 11, 139-156. doi: 10.1016/j.jmarsys.2012.10.009

Pecl, G. T., Araujo, M. B., Bell, J. D., Blanchard, J., Bonebrake, T. C., Chen, I. C., et al. (2017). Biodiversity redistribution under climate change: impacts on ecosystems and human well-being. Science 355, 1-53. doi: 10.1126/science. aai9214

Perry, A. L., Low, P. J., Ellis, J. R., and Reynolds, J. D. (2005). Climate change and distribution shifts in marine fishes. Science 308, 1912-1915. doi: 10.1126/ science. 1111322

Poloczanska, E. S., Brown, C. J., Sydeman, W. J., Kiessling, W., Schoeman, D. S., Moore, P. J., et al. (2013). Global imprint of climate change on marine life. Nat. Clim. Chang. 3, 919-925.

Reed, D., Washburn, L., Rassweiler, A., Miller, R., Bell, T., and Harrer, S. (2016). Extreme warming challenges sentinel status of kelp forests as indicators of climate change. Nat. Commun. 7, 13757. doi: 10.1038/ncomms13757

Schaeffer, A., and Roughan, M. (2017). Subsurface intensification of marine heatwaves off Southeastern Australia: the role of stratification and local winds. Geophys. Res. Lett. 44, 5025-5033. doi: 10.1002/2017gl073714

Scheffer, M., and Carpenter, S. R. (2003). Catastrophic regime shifts in ecosystems: linking theory to observation. Trends Ecol. Evol. 18, 648-656. doi: 10.1016/j. tree.2003.09.002

Serisawa, Y., Imoto, Z., Ishikawa, T., and Ohno, M. (2004). Decline of the Ecklonia cava population associated with increased seawater temperatures in tosa bay, Southern Japan. Fish. Sci. 70, 189-191. doi: 10.1111/j.0919-9268.2004.00788.x

Shea, K., Roxburgh, S. H., and Rauschert, S. J. (2004). Moving from pattern to process:coexistence mechanisms under intermediate disturbance regimes. Ecol. Lett. 7, 491-508. doi: 10.1111/j.1461-0248.2004.00600.x

Short, J., Foster, T., Falter, J., Kendrick, G. A., and McCulloch, M. T. (2015). Crustose Coralline algal growth, calcification and mortality following a marine heatwave in Western Australia. Cont. Shelf Res. 106, 38-44. doi: 10.1016/j.csr. 2015.07.003

Smale, D. A., and Wernberg, T. (2012). Ecological observations associated with an anomalous warming event at the Houtman Abrolhos Islands, Western Australia. Coral Reefs 31:441. doi: 10.1007/s00338-012-0873-4

Smale, D. A., and Wernberg, T. (2013). Extreme climatic event drives range contraction of a habitat-forming species. Proc. Biol. Sci. 280:20122829. doi: 10.1098/rspb.2012.2829

Smale, D. A., Wernberg, T., and Vanderklift, M. A. (2017). Regional-scale variability in the response of benthic macroinvertebrate assemblages to a marine heatwave. Mar. Ecol. Prog. Ser. 568, 17-30. doi: 10.3354/meps12080

Smale, D. A., Wernberg, T., Oliver, E. C. J., Thomsen, M. S., Harvey, B. P., Straub, S. C., et al. (2019). Marine heatwaves threaten global biodiversity and the provision of ecosystem services. Nat. Clim. Chang. 9, 306-312. doi: 10.1038/ s41558-019-0412-1

Sorte, C. J. B., Williams, S. L., and Carlton, J. T. (2010). Marine range shifts and species introductions: comparative spread rates and community impacts. Glob. Ecol. Biogeogr. 19, 303-316. doi: 10.1111/j.1466-8238.2009.00519.x

Soto, R. (1985). Efectos Del Fenomeno El Nino 1982-83 en ecosistemas de la 1 region. Investigación Pesquera 32, 199-206.

Sousa, W. P. (1984). The role of disturbance in natural communities. Annu. Rev. Ecol. Syst. 15, 353-391. doi: 10.1146/annurev.es.15.110184.002033
Southward, A. J., Hawkins, S. J., and Burrows, M. (1995). Seventy years' observations of changes in distribution and abundance of zooplankton and intertidal organisms in the western english channel in relation to rising sea temperature. J. Therm. Biol. 1, 127-155. doi: 10.1016/0306-4565(94) 00043-i

Steneck, R. S., and Johnson, C. R. (2013). "Kelp forests: dynamic patterns, processes, and feedbacks," in Marine Community Ecology, eds M. Bertness, J. Bruno, B. Silliman, and J. Stachowicz, (Sunderland, MA: Sinauer Associates), 315-336.

Takao, S., Kumagai, N. H., Yamano, H., Fujii, M., and Yamanaka, Y. (2015). Projecting the impacts of rising seawater temperatures on the distribution of seaweeds around Japan under multiple climate change scenarios. Ecol. Evol. 5, 213-223. doi: 10.1002/ece3.1358

Tanaka, K., Taino, S., Haraguchi, H., Prendergast, G., and Hiraoka, M. (2012). Warming off Southwestern Japan linked to distributional shifts of subtidal canopy-forming seaweeds. Ecol. Evol. 2, 2854-2865. doi: 10.1002/ece3.391

Teagle, H., Hawkins, S. J., Moore, P. J., and Smale, D. A. (2017). The Role of Kelp Species as Biogenic Habitat Formers in Coastal Marine Ecosystems Marine Ecosystems. Journal of Experimental Marine Biology and Ecology 497, 81-98. doi: 10.1016/j.jembe.2017.01.017

Tegner, M. J., Dayton, P. K., Edwards, P. B., and Riser, K. L. (1997). Large-scale, low-frequency oceanographic effects on kelp forest succession: a tale of two cohorts. Mar. Ecol. Prog. Ser. 146, 117-134. doi: 10.3354/meps 146117

Thomsen, M. S., and South, P. M. (2019). Communities and attachment networks associated with primary, secondary and alternative foundation species; a case study of stressed and disturbed stands of Southern Bull Kelp. Diversity 11:56. doi: 10.3390/d11040056

Thomsen, M. S., Mondardini, L., Gerrity, S., Tait, L., South, P., Lilley, S., et al. (2019). Local extinction of bull kelp (Durvillaea spp.) due to a marine heatwave. Front. Mar. Sci. 5:84. doi: 10.3389/fmars.2019.00084

Tuya, F. T. W., and Thomsen, M. S. (2009). Habitat structure affect abundances of labrid fishes across temperate reefs in South-Western Australia. Environ. Biol. Fish. 86, 311-319. doi: 10.1007/s10641-009-9520-5

Tuya, F., Cacabelos, E., Duarte, P., Jacinto, D., Castro, J. J., Silva, T., et al. (2012). Patterns of landscape and assemblage structure along a latitudinal gradient in ocean climate. Mar. Ecol. Prog. Ser. 466, 9-19. doi: 10.3354/meps09941

Van den Hoek, C. (1982). The distribution of benthic marine algae in relation to the temperature regulation of their life histories. Biol. J. Linn. Soc. 18, 81-144. doi: 10.1111/j.1095-8312.1982.tb02035.x

Vergés, A., Doropoulos, C., Malcolm, H. A., Skye, M., Garcia-Pizá, M., Marzinelli, E. M., et al. (2016). Long-term empirical evidence of ocean warming leading to tropicalization of fish communities, increased herbivory, and loss of kelp. PNAS 113, 13791-13796. doi: 10.1073/pnas.1610725113

Vergés, A., Steinberg, P. D., Hay, M. E., Poore, A. G. B., Campbell, A. H., Ballesteros, E., et al. (2014a). The tropicalization of temperate marine ecosystems: climate-mediated changes in herbivory and community phase shifts. Proc. R. Soc. B 281:20140846. doi: 10.1098/rspb.2014.0846

Vergés, A., Tomas, F., Cebrian, E., Ballesteros, E., Kizilkaya, Z., Dendrinos, P., et al. (2014b). Tropical rabbitfish and the deforestation of a warming temperate Sea. J. Ecol. 102, 1518-1527. doi: 10.1111/1365-2745.12324

Wernberg, T. (2019). "Marine heatwave drives collapse of kelp forests in Western Australia," in Ecosystem Collapse and Climate Change, eds J. Canadell, and R. Jackson, (Berlin: Springer-Nature).

Wernberg, T. S., Bennett, R. C., Babcock, T., de Bettignies, K., Cure, M., Depczynski, F., et al. (2016). Climate-driven regime shift of a temperate marine ecosystem. Science 353, 169-172. doi: 10.1126/science.aad8745

Wernberg, T., and Filbee-Dexter, K. (2019). Missing the marine forest for the trees. Mar. Ecol. Prog. Ser. 612, 209-215. doi: 10.3354/meps12867

Wernberg, T., and Straub, S. C. (2016). "Impacts and effects of ocean warming on seaweeds," in Explaining Ocean Warming: Causes, Scale, Effects and Consequences, eds D. Laffoley, and J. Baxter, (Gland: IUCN), 87-103.

Wernberg, T., Coleman, M. A., Bennett, S., Thomsen, M., Tuya, F., and Kelaher, B. P. (2018a). Genetic diversity and kelp forest vulnerability to climatic stress. Sci. Rep. 8, 1-8. doi: 10.1038/s41598-018-20009-9

Wernberg, T., Kendrick, G. A., and Phillips, J. C. (2003). Regional differences in kelp-associated algal assemblages on temperate limestone reefs in SouthWestern Australia. Divers. Distribut. 9, 427-441. doi: 10.1046/j.1472-4642. 2003.00048.x 
Wernberg, T., Krumhansl, K. A., Filbee-Dexter, K., and Pedersen, M. F. (2019). "Status and trends for the world' s kelp forests," in World Seas: An Environmental Evaluation, ed. C. Sheppard, (Amsterdam: Elsevier), 57-78. doi: 10.1016/b978-0-12-805052-1.00003-6

Wernberg, T., Krumhansl, K., Filbee-Dexter, K., and Pedersen, M. F. (2018b). "Status and trends for the world's kelp forests," in World Seas: An Environmental Evaluation, Vol III: Ecological Issues and Environmental Impacts, ed. C. Sheppard, (Amsterdam: Elsevier). doi: 10.1016/b978-0-12-805052-1.00 003-6

Wernberg, T., Russell, B. D., Moore, P. J., Ling, S. D., Smale, D. A., Campbell, A., et al. (2011a). Impacts of climate change in a global hotspot for temperate marine biodiversity and ocean warming. J. Exp. Mar. Biol. Ecol. 400, 7-16. doi: 10.1016/j.jembe.2011.02.021

Wernberg, T., Russell, B. D., Thomsen, M. S., Gurgel, C. F., Bradshaw, C. J., Poloczanska, E. S., et al. (2011b). Seaweed communities in retreat from ocean warming. Curr. Biol. 21, 1828-1832. doi: 10.1016/j.cub.2011.09.028

Wernberg, T., Smale, D. A., and Thomsen, M. S. (2012). A decade of climate change experiments on marine organisms: procedures, patterns and problems. Glob. Chang. Biol. 18, 1491-1498. doi: 10.1111/j.1365-2486.2012.02656.x

Wernberg, T., Smale, D. A., Tuya, F., Thomsen, M. S., Langlois, T. L., de Bettignies, T., et al. (2013a). An extreme climatic event alters marine ecosystem structure in a global biodiversity hotspot. Nat. Clim. Chang. 3, 78-82. doi: 10.1038/ nclimate 1627

Wernberg, T., Thomsen, M. S., Connell, S. D., Russell, B. D., Waters, J. M., Zuccarello, G. C., et al. (2013b). The footprint of continental-scale ocean currents on the biogeography of seaweeds. PLoS One 8:e0080168. doi: 10.1371/ journal.pone.0080168

Wernberg, T., Thomsen, M. S., Tuya, F., Kendrick, G. A., Staehr, P. A., and Toohey, B. D. (2010). Decreasing resilience of kelp beds along a latitudinal temperature gradient: potential implications for a warmer future. Ecol. Lett. 13, 685-694. doi: 10.1111/j.1461-0248.2010.01466.x

Xiao, X., de Bettignies, T., Olsen, Y. S., Agusti, S., Duarte, C. M., and Wernberg, T. (2015). Sensitivity and acclimation of three canopy-forming seaweeds to UVB radiation and Warming. PLoS One 10:e0143031. doi: 10.1371/journal. pone. 0143031

Zarco-Perello, S., Wernberg, T., Langlois, T. J., and Vanderklift, M. A. (2017). Tropicalization strengthens consumer pressure on habitat- forming seaweeds. Sci. Rep. 7:820. doi: 10.1038/s41598-017-00991-2

Conflict of Interest: The authors declare that the research was conducted in the absence of any commercial or financial relationships that could be construed as a potential conflict of interest.

Copyright (c) 2019 Straub, Wernberg, Thomsen, Moore, Burrows, Harvey and Smale. This is an open-access article distributed under the terms of the Creative Commons Attribution License (CC BY). The use, distribution or reproduction in other forums is permitted, provided the original author(s) and the copyright owner(s) are credited and that the original publication in this journal is cited, in accordance with accepted academic practice. No use, distribution or reproduction is permitted which does not comply with these terms. 